\title{
Comparative Effect between Sardine Oil and Fish Oil Rich in Omega-3 Fatty Acids on Hypertension and the Membrane Composition of Adipocytes in SHR Rats
}

\author{
Rosa María Oliart Ros ${ }^{1}$, Ida Soto Rodríguez ${ }^{3}$, María Guadalupe Sánchez OTERo ${ }^{3}$, \\ Oscar M. López $\mathrm{GIL}^{2}$, Israel EscoBAR-SAGASTUME ${ }^{2}$ and Alfonso ALEXANDER-AGUILERA ${ }^{2,3, *}$ \\ ${ }^{1}$ UNIDA, Instituto Tecnológico de Veracruz, M.A. de Quevedo 2779, \\ Col. Formando Hogar, Veracruz, Ver. 91897, México \\ ${ }^{2}$ Escuela de Medicina, Universidad Cristóbal Colón, Carr. Veracruz-Medellin s/n, \\ Col. Puente Moreno, Boca del Río, Ver. 94271, México \\ ${ }^{3}$ Facultad de Bioanálisis, Universidad Veracruzana, Carmen Serdán s/n, \\ Col. Flores Magón, Veracruz, Ver. 91700, México \\ (Received April 29, 2017)
}

\begin{abstract}
Summary Omega-3 polyunsaturated fatty acids, have an important role in reducing hypertriglyceridemia, these acids decrease the mortality for Coronary Heart Disease. Very important is the relationship between fatty acid biosynthesis and distribution in organs and tissues involved in insulin resistance and hypertension due to its role in the production of vasoactive eicosanoids and their effects on insulin sensitivity; which is estimated with the HOMA-IR index, which relates the physiological and metabolic behavior of glucose and insulin in the body. The aim of this project was to compare the effect of sardine oil and omega-3 oils rich in polyunsaturated fatty acids: EPA $(\approx 30 \%)$ and DHA $(\approx 50 \%)$ administered for 6 to $8 \mathrm{wk}$ respectively; on the lipid composition of the plasma membrane of epididymal adipocytes in spontaneously hypertensive rats (SHR) and their relation to obesity, insulin resistance and hypertension. The administration of omega- 3 enriched oil significantly decreased the HOMA criteria as an insulin resistance indicator compared to the sardine oil. Key Words fish oil, hypertension, membrane composition, omega-3 fatty acids, sardine oil
\end{abstract}

Hypertension is an important risk factor for cardiovascular and cerebrovascular morbidity and mortality (1). Significant collaborative efforts to combat hypertension in low- and middle-income countries are urgently needed (2). Different factors have an effect on deficient control of hypertension, for example poor adherence to treatment, unhealthy lifestyles and bad eating habits (3).

There is a permanent interest in knowing how dietary fat affects the alterations associated with insulin resistance and its related cardiovascular disorders such as hypertension.

Long-chain (omega-3) polyunsaturated fatty acids (n-3 PUFAs) from some marine products such as fish oil have attracted important attention in recent years. Fish oil, a rich source of $n-3$ PUFA, has an important role in reducing hypertriglyceridemia, improves several determinant metabolic factors of cardiovascular risk, and decreases mortality from coronary heart disease (4). The interrelationship between the cellular synthesis of fatty acids and their distribution in organs and tissues related to insulin dependence and hypertension is of considerable importance because of their role in the biosynthesis of vasoactive eicosanoids and their effects on membrane properties that regulate insulin sensitivity (5).

\footnotetext{
*To whom correspondence should be addressed.

E-mail: aalexander_2000@yahoo.com or aalexander@uv.mx
}

With respect to the above, the amount of $n-3$ PUFA that needs to be in the diet to provide health effects is still unknown. All fish contain EPA and DHA in amounts that vary depending on species, the ratio in fish ranges between 0.22 and 1.25 . There is controversy about the amounts of $n-3$ PUFAs, in particular DHA or EPA, that can have a positive effect on the prevention of metabolic disorders and cardiovascular disease (CVD). FAO/WHO, the American Dietetic Association and American Heart Association now recommend dietary intakes for total $n$-3 PUFA of 1.4 to $2.5 \mathrm{~g} / \mathrm{d}$, with EPA and DHA ranging from 140 to $600 \mathrm{mg} / \mathrm{d}$, depending on the authority issuing the guidelines. It is very important to know the impact of increasing the concentration of dietary n-3 fatty acids on the composition of the plasma membrane of adipocytes and their relationship with insulin resistance and hypertension; since the plasma membrane provides fatty acids for different cellular functions, including the production of eicosanoids related to vascular tone and hypertension (6).

In relation to the above, it is not clear whether the increase in the dietary consumption of $n-3$ PUFA improves the concentration in the plasma membrane of adipocytes and proportionally reduces blood pressure.

The present study evaluated the comparative effect of two oils (sardine oil and fish oil rich in n-3 PUFAs) on hypertension and insulin resistance, and their relation with the fatty acid composition of the membrane of adi- 
Table 1. Composition of diets administered to rats.

\begin{tabular}{lccc}
\hline Ingredients & $\begin{array}{c}\text { Fish oil } \\
\text { diet } \\
(\mathrm{g})\end{array}$ & $\begin{array}{c}\text { Sardine oil } \\
\text { diet } \\
(\mathrm{g})\end{array}$ & $\begin{array}{c}\text { Sunflower oil } \\
\text { diet } \\
(\mathrm{g})\end{array}$ \\
\hline Casein & 440 & 440 & 440.0 \\
DL-Methionine & 3.1 & 3.1 & 3.1 \\
Cellulose & 40 & 40 & 40 \\
Cornstarch & 658 & 658 & 658 \\
Vitamin mix ${ }^{1}$ & 20 & 20 & 20 \\
Mineral mix $^{2}$ & 80 & 80 & 80 \\
BHT & 0.4 & 0.4 & 0.4 \\
Sunflower oil & - & - & 100 \\
Fish oil & 100 & - & - \\
Sardine oil & - & 100 & - \\
\hline
\end{tabular}

\footnotetext{
${ }^{1}$ Vitamin mix (Teklad 40060).

${ }^{2}$ Mineral mix (Teklad IIN-76 170915).

${ }^{3}$ Butylated hydroxytoluene.
}

pocytes in spontaneously hypertensive rats (SHRs).

\section{MATERIALS AND METHODS}

Materials. The sardine oil and fish oil rich in n-3 PUFAs used were obtained from Sonora University, Mexico; and Ocean Nutrition (San Diego, CA) respectively. Male Kyoto Wistar (KW) rats, spontaneously hypertensive rats (SHR) and dietary feed components were purchased from Harlan Teklad Inc. (Mexico City, Mexico).

Experimental design. Utilized were 40 male SHR rats and 20 male KW rats $(21 \mathrm{~d}$ old). The rats were individually housed, and maintained on a 12-h light/dark cycle at $25^{\circ} \mathrm{C}$. Animal handling and maintenance was realized in accordance with the National Institute of Health's Guide for the Care and Use of Laboratory Animals (1985) (7). We worked two experimental designs; the first one consisted of three groups: a sunflower oil group (SF-SHR; $n=10$ ), receiving a diet with $7.5 \%$ of this oil as the lipid source; a sardine oil group (SO-SHR; $n=10)$ receiving $7.5 \%$ of this oil; and a control group (KW; $n=10$ ) receiving a diet with $7.5 \%$ sunflower oil. Rats ingested the diets ad libitum during $6 \mathrm{wk}$. The second experimental design consisted of three groups: The SF-SHR group in which SHR rats received a diet with $7.5 \%$ sunflower oil as the lipid source; the FO-SHR group in which SHR rats received a diet with $7.5 \%$ of fish oil rich in omega-3 fatty acid ([EPA 27.22 $\pm 0.15 \%$ and DHA 50.55 $\pm 0.30 \%]$ Ocean Nutrition); and the control group (KW; $n=10)$ in which $\mathrm{KW}$ rats received the $7.5 \%$ sunflower oil diet. For $8 \mathrm{wk}$, the rats had ad libitum access to the diets which were prepared with $0.02 \%$ BHT as an antioxidant and stored under refrigeration until used. Tables 1 and 2 show the ingredients of diets and their fatty acid composition.

At the end of the experimental treatments, body weight and blood pressure were measured; after 18 to $20 \mathrm{~h}$ of fasting, the animals were sacrificed. Serum was obtained by centrifugation of blood at 3,000 rpm, for $15 \mathrm{~min}$, at $4^{\circ} \mathrm{C}$. Epididymal fat pads were weighed and immediately frozen at $70^{\circ} \mathrm{C}$ until their use.
Table 2. Fatty acid composition of oils used in diet preparations.

\begin{tabular}{|c|c|c|c|}
\hline Fatty acid & $\begin{array}{l}n-3 \text { enriched } \\
\text { fish oil }\end{array}$ & Sardine oil & Sunflower oil \\
\hline 14:0 & $0.37 \pm 0.01^{\mathrm{a}}$ & $7.28 \pm 1.09^{b}$ & $0.55 \pm 0.01^{\mathrm{c}}$ \\
\hline 16:0 & $1.28 \pm 0.01^{\mathrm{a}}$ & $26.99 \pm 3.90^{b}$ & $12.80 \pm 0.07^{\mathrm{c}}$ \\
\hline 18:0 & $1.66 \pm 0.14^{\mathrm{a}}$ & $8.20 \pm 1.20^{b}$ & $\mathrm{Nd}$ \\
\hline Total & $3.31 \pm 0.16^{\mathrm{a}}$ & $42.47 \pm 6.37^{b}$ & $13.35 \pm 0.08^{c}$ \\
\hline $16: 1$ & $0.76 \pm 0.01^{\mathrm{a}}$ & $6.34 \pm 0.91^{b}$ & $\mathrm{Nd}$ \\
\hline $18: 1$ & $3.11 \pm 0.01^{\mathrm{a}}$ & $15.1 \pm 2.26^{b}$ & $50.70 \pm 0.28^{c}$ \\
\hline Total & $3.87 \pm 0.02^{\mathrm{a}}$ & $21.64 \pm 3.24^{b}$ & $50.70 \pm 0.28^{c}$ \\
\hline $18: 2(n-6)$ & $5.18 \pm 0.90^{\mathrm{a}}$ & $0.48 \pm 0.07^{\mathrm{b}}$ & $32.80 \pm 0.12^{\mathrm{c}}$ \\
\hline $20: 4(n-6)$ & $1.20 \pm 0.03^{\mathrm{a}}$ & $0.36 \pm 0.05^{b}$ & $\mathrm{Nd}$ \\
\hline Total & $6.38 \pm 0.93^{\mathrm{a}}$ & $0.84 \pm 0.12^{b}$ & $32.80 \pm 0.12^{\mathrm{c}}$ \\
\hline $18: 3(n-3)$ & $0.28 \pm 0.04^{\mathrm{a}}$ & $2.85 \pm 0.42^{\mathrm{b}}$ & $3.50 \pm 0.03^{c}$ \\
\hline 20:5 EPA & $27.22 \pm 0.15^{\mathrm{a}}$ & $20 \pm 3.00^{\mathrm{b}}$ & $\mathrm{Nd}$ \\
\hline 22:5 DPA & $9.92 \pm 0.10$ & $\mathrm{Nd}$ & $\mathrm{Nd}$ \\
\hline 22:6 DHA & $50.05 \pm 0.30^{\mathrm{a}}$ & $13 \pm 1.95^{b}$ & $\mathrm{Nd}$ \\
\hline Total & $87.47 \pm 0.59^{a}$ & $35.85 \pm 5.37^{b}$ & $3.50 \pm 0.03^{c}$ \\
\hline
\end{tabular}

a,b,c $p<0.05$.

Values are expressed as percentage of total fatty acids. Nd: not detected.

Blood pressure measurement. Systolic blood pressure was measured by a tail-cuff method (IITC noninvasive blood pressure system, model 29; Life Science Instruments, Woodland Hills, CA) while animals were conscious. The resultant blood pressure value is the mean of five systolic measurements. These measurements were made after 6 and $8 \mathrm{wk}$ of treatment with the experimental diets.

Glucose and insulin measurement. Serum insulin levels was determined by a commercial double-antibody solid-phase radioimmunoassay (Coat-A-Count, DPC), and serum glucose concentration was measured by the glucose oxidase method.

HOMA-IR. The homeostasis model assessment of insulin resistance (HOMA-IR) index was obtained with the following formula: [insulin in blood in fasting $(\mu \mathrm{U} /$ $\mathrm{mL})] \times[$ blood glucose in fasting $(\mathrm{mmol} / \mathrm{L})] / 22.5(8)$.

Isolation of adipocytes and preparation of plasma membranes. Epididymal adipocytes were isolated from fat tissue using 1-2 $\mathrm{g}$ of fresh tissue, which was homogenized in Bouskella-Ringer-Tris buffer, pH 7.4 at $4^{\circ} \mathrm{C}$ with a Teflon pestle homogenizer (Daigger) and centrifuged at $40,000 \times g$ for $40 \mathrm{~min}$ at $4^{\circ} \mathrm{C}$. Later, the plasma membranes were separated from the precipitates obtained by a Percoll gradient at $10,000 \times g$ for $15 \mathrm{~min}$ (9).

Lipid extraction and fatty acid composition determination. Lipids from diets and plasma membrane preparations were extracted according to the Folch method (10). Fatty acids were methylated (1 N HCl-methanol) and analyzed by gas chromatography (Hewlett-Packard gas chromatograph model 6890-Andover, MA), equipped with a 60-m Supelcowax-10 capillary column and a flame ionization detector. Injection and detector 

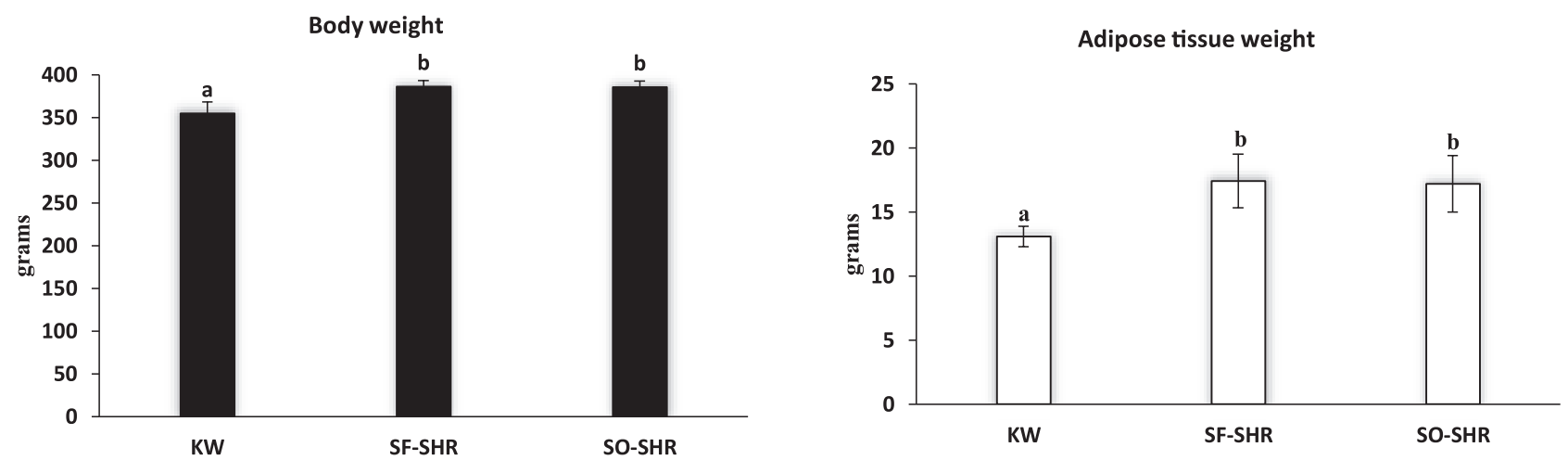

Fig. 1. Total body $\left({ }^{\mathrm{a}, \mathrm{b}} p<0.05\right)$ and adipose tissue weight after 6 wk of sardine oil administration $\left({ }^{\mathrm{a}, \mathrm{b}} p<0.01\right)$. KW group $(n=10)$, SF-SHR group $(n=10)$, SO-SHR $(n=10)$ group. Values represent the mean \pm SD.
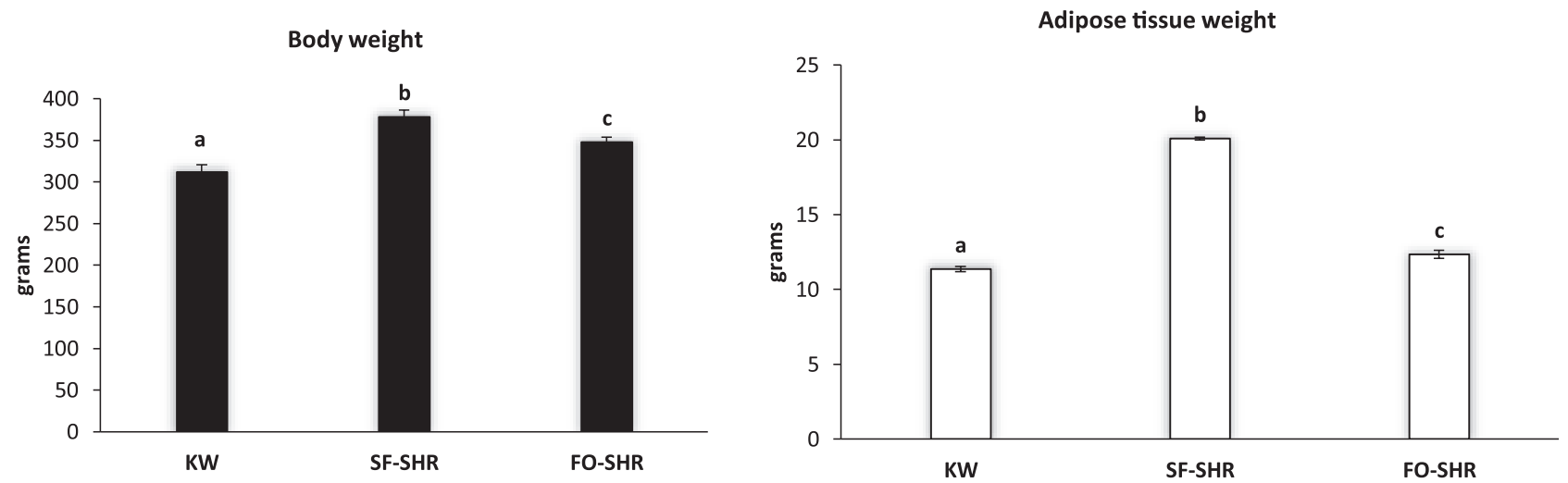

Fig. 2. Total body $\left({ }^{\mathrm{a}, \mathrm{b}, \mathrm{c}} p<0.05\right)$ and adipose tissue weight after 8 wk administration of fish oil rih in $n-3$ PUFA ( $\left.{ }^{\mathrm{a}, \mathrm{b}, \mathrm{c}} p<0.01\right)$. KW group $(n=10)$, SF-SHR group $(n=10)$, FO-SHR $(n=10)$ group. Values represent the mean \pm SD.

temperatures were maintained at $250^{\circ} \mathrm{C}$, nitrogen was the carrier gas, and the column temperature was programmed to rise from 100 to $210^{\circ} \mathrm{C}$ at a rate of $2^{\circ} \mathrm{C} / \mathrm{min}$. Fatty acid methyl esters were identified by comparison with the corresponding fatty acid standards (Sigma).

Data analysis. Data is shown as the mean \pm SD. Statistical significance was determined by ANOVA, and Tukey's multiple range test was utilized for mean comparison $(p<0.05)$.

\section{RESULTS}

Body weight, total adipose tissue

Figures 1 and 2 show the results of body weight and total adipose tissue; as can be seen, SHR groups had a higher body and adipose tissue weight, in comparison with KW control rats. Sardine oil administration during 6 wk did not produce any change in these parameters; however, after 8 wk of consuming fish oil rich in $n-3$ PUFAs a significant reduction in body weight $(8 \%)$ and adipose tissue weight $(38 \%)$ were observed, in comparison with SHR rats fed the sunflower oil diet.

Fatty acid composition of adipocytes membranes

The fatty acid profiles of the membrane lipids of epididymal adipocytes of the rats were modified in accordance to the fatty acid composition of the diets administered. Rats fed the sardine oil diet, showed lower levels of monounsaturated and polyunsaturated n-6 fatty acids with respect to KW and SHR rats which were fed the sunflower oil diet, while rats fed the $n-3$ polyunsaturated fatty acids showed a significantly augmented incorporation of EPA and DHA in membranes (3-fold and 4-fold respectively), with respect to SHR rats fed the sunflower oil diet (Table 3).

In a similar way, rats fed with omega-3 enriched fish oil also exhibited lower levels of n-6 PUFA in membranes in comparison with SHR rats fed with sunflower oil, and an increase in n-3 PUFA. A higher incorporation of EPA and DHA (4-fold and 5-fold respectively) was observer, in comparison with SHR rats fed sunflower oil (Table 4). These changes resulted in a significant modification of the $n-6 / n-3$ relation; while SHR rats fed the sunflower oil diet showed elevated $n-6 / n-3$ ratios $(59.03 \pm 11.49$ and $44.35 \pm 3.88$ ), the SHR rats fed sardine oil and fish oil with a higher concentration of omega- 3 presented a decrease in the $n-6 / n-3$ relation $(2.72 \pm 0.01$ and 2.35 \pm 0.05 , respectively).

Blood pressure, HOMA-IR and n-6/n-3 fatty acids ratio

Table 5 depicts the results of the blood pressure and insulin resistance in rats fed with sardine oil and $n-3$ enriched fish oil. As expected, SHR groups fed sunflower oil diets had a significant higher blood pressure with respect to KW control rats $(39 \%$ and $56 \%)$. After consuming sardine oil during $6 \mathrm{wk}$, blood pressure diminished by $28 \%$ in this group, and the rats ingesting $n-3$ 
Table 3. Fatty acid composition of adipocyte membranes of rats fed sardine oil diet during $6 \mathrm{wk}$.

\begin{tabular}{lrrr}
\hline & KW & SF-SHR & \multicolumn{1}{c}{ SO-SHR } \\
\hline $14: 0$ & $0.70 \pm 0.05^{\mathrm{a}}$ & $0.97 \pm 0.30^{\mathrm{a}}$ & $0.74 \pm 0.19^{\mathrm{a}}$ \\
$15: 0$ & $0.20 \pm 0.04^{\mathrm{a}}$ & $0.18 \pm 0.02^{\mathrm{a}}$ & $0.17 \pm 0.04^{\mathrm{a}}$ \\
$16: 0$ & $22.44 \pm 2.10^{\mathrm{a}}$ & $22.84 \pm 0.96^{\mathrm{a}}$ & $19.60 \pm 2.38^{\mathrm{b}}$ \\
$17: 0$ & $0.40 \pm 2.10^{\mathrm{a}}$ & $0.79 \pm 0.14^{\mathrm{b}}$ & $0.38 \pm 0.08^{\mathrm{c}}$ \\
$18: 0$ & $18.28 \pm 2.15^{\mathrm{a}}$ & $14.73 \pm 2.48^{\mathrm{a}}$ & $17.22 \pm 0.42^{\mathrm{a}}$ \\
$20: 0$ & $0.60 \pm 0.11^{\mathrm{a}}$ & $0.79 \pm 0.21^{\mathrm{a}}$ & $0.46 \pm 0.01^{\mathrm{b}}$ \\
$16: 1$ & $1.78 \pm 0.30^{\mathrm{a}}$ & $1.35 \pm 0.01^{\mathrm{a}}$ & $3.17 \pm 0.24^{\mathrm{b}}$ \\
$18: 1$ & $20.06 \pm 7.90^{\mathrm{a}}$ & $21.36 \pm 4.61^{\mathrm{a}}$ & $15.59 \pm 1.73^{\mathrm{b}}$ \\
$24: 1$ & $1.70 \pm 0.21^{\mathrm{a}}$ & $1.62 \pm 0.23^{\mathrm{a}}$ & $1.27 \pm 0.06^{\mathrm{b}}$ \\
$18: 2(n-6)$ & $10.20 \pm 5.15^{\mathrm{a}}$ & $10.48 \pm 0.22^{\mathrm{a}}$ & $10.77 \pm 0.03^{\mathrm{a}}$ \\
$18: 3(n-6)$ & $1.70 \pm 0.10^{\mathrm{a}}$ & $3.87 \pm 0.04^{\mathrm{b}}$ & $6.03 \pm 0.01^{\mathrm{c}}$ \\
$20: 4(n-6)$ & $20.62 \pm 0.20^{\mathrm{a}}$ & $20.49 \pm 0.44^{\mathrm{a}}$ & $14.16 \pm 0.06^{\mathrm{b}}$ \\
$18: 3(n-3)$ & $0.08 \pm 0.01^{\mathrm{a}}$ & $0.08 \pm 0.01^{\mathrm{a}}$ & $9.70 \pm 0.38^{\mathrm{b}}$ \\
$20: 5(n-3)$ & $0.10 \pm 0.01^{\mathrm{a}}$ & $0.17 \pm 0.02^{\mathrm{a}}$ & $0.67 \pm 0.03^{\mathrm{b}}$ \\
$22: 6(n-3)$ & $0.28 \pm 0.02^{\mathrm{a}}$ & $0.33 \pm 0.04^{\mathrm{a}}$ & $0.98 \pm 0.12^{\mathrm{b}}$ \\
Total PUFA & $33.56 \pm 5.51^{\mathrm{a}}$ & $35.42 \pm 0.77^{\mathrm{a}}$ & $42.31 \pm 0.64^{\mathrm{b}}$ \\
$n-6 / n-3$ & $71.95 \pm 17.51^{\mathrm{a}}$ & $59.03 \pm 11.94^{\mathrm{b}}$ & $2.72 \pm 0.01^{\mathrm{c}}$ \\
\hline
\end{tabular}

Values are expressed as percentage of total fatty acid (mean of $\% \pm \mathrm{SD}$ ).

Different letters represent differences between groups, $p<0.01$.
Table 4. Fatty acid composition of adipocyte membranes of rats fed. $n$-3 PUFA fish oil diet during $8 \mathrm{wk}$.

\begin{tabular}{lrrr}
\hline & KW & \multicolumn{1}{c}{ SF-SHR } & \multicolumn{1}{c}{ FO-SHR } \\
\hline $14: 0$ & $0.73 \pm 0.04^{\mathrm{a}}$ & $0.95 \pm 0.21^{\mathrm{b}}$ & $0.77 \pm 0.13^{\mathrm{a}}$ \\
$15: 0$ & $0.17 \pm 0.04^{\mathrm{a}}$ & $0.22 \pm 0.03^{\mathrm{a}}$ & $0.17 \pm 0.03^{\mathrm{a}}$ \\
$16: 0$ & $23.23 \pm 1.97^{\mathrm{a}}$ & $22.87 \pm 0.92^{\mathrm{a}}$ & $21.44 \pm 2.22^{\mathrm{a}}$ \\
$17: 0$ & $0.42 \pm 0.01^{\mathrm{a}}$ & $0.69 \pm 0.11^{\mathrm{b}}$ & $0.36 \pm 0.09^{\mathrm{c}}$ \\
$18: 0$ & $18.82 \pm 1.87^{\mathrm{a}}$ & $11.89 \pm 1.92^{\mathrm{b}}$ & $15.67 \pm 0.92^{\mathrm{a}}$ \\
$20: 0$ & $0.63 \pm 0.12^{\mathrm{a}}$ & $0.75 \pm 0.23^{\mathrm{a}}$ & $0.42 \pm 0.01^{\mathrm{b}}$ \\
$16: 1$ & $1.69 \pm 0.35^{\mathrm{a}}$ & $1.45 \pm 0.03^{\mathrm{a}}$ & $2.89 \pm 0.01^{\mathrm{b}}$ \\
$18: 1$ & $22.12 \pm 4.31^{\mathrm{a}}$ & $23.67 \pm 1.23^{\mathrm{a}}$ & $18.79 \pm 1.11^{\mathrm{a}}$ \\
$24: 1$ & $1.78 \pm 0.22^{\mathrm{a}}$ & $1.68 \pm 0.12^{\mathrm{b}}$ & $1.28 \pm 0.04^{\mathrm{c}}$ \\
$18: 2(n-6)$ & $10.34 \pm 2.01^{\mathrm{a}}$ & $11.45 \pm 0.65^{\mathrm{a}}$ & $10.32 \pm 0.45^{\mathrm{a}}$ \\
$18: 3(n-6)$ & $1.56 \pm 0.34^{\mathrm{a}}$ & $2.81 \pm 0.57^{\mathrm{b}}$ & $3.78 \pm 0.03^{\mathrm{c}}$ \\
$20: 4(n-6)$ & $17.35 \pm 0.07^{\mathrm{a}}$ & $20.78 \pm 0.05^{\mathrm{b}}$ & $13.42 \pm 0.23^{\mathrm{c}}$ \\
$18: 3(n-3)$ & $0.26 \pm 0.02^{\mathrm{a}}$ & $0.09 \pm 0.02^{\mathrm{b}}$ & $7.79 \pm 0.12^{\mathrm{c}}$ \\
$20: 5(n-3)$ & $0.55 \pm 0.12^{\mathrm{a}}$ & $0.37 \pm 0.06^{\mathrm{b}}$ & $1.79 \pm 0.07^{\mathrm{c}}$ \\
$22: 6(n-3)$ & $0.35 \pm 0.07^{\mathrm{a}}$ & $0.33 \pm 0.03^{\mathrm{b}}$ & $2.10 \pm 0.09^{\mathrm{c}}$ \\
Total PUFA & $30.45 \pm 2.63^{\mathrm{a}}$ & $35.83 \pm 1.38^{\mathrm{b}}$ & $39.50 \pm 0.99^{\mathrm{c}}$ \\
$n-6 / n-3$ & $25.21 \pm 3.32^{\mathrm{a}}$ & $44.35 \pm 3.88^{\mathrm{b}}$ & $2.35 \pm 0.05^{\mathrm{c}}$ \\
\hline
\end{tabular}

Values are expressed as percentage of total fatty acid (mean of $\% \pm S D$ ).

Different letters represent differences between groups, $p<0.01$.

Table 5. Blood pressure, HOMA-IR in rats fed with the experimental diets.

\begin{tabular}{|c|c|c|c|}
\hline & \multicolumn{3}{|c|}{$6 \mathrm{wk}$} \\
\hline & KW group & SF-SHR group & SO-SHR group \\
\hline $\begin{array}{l}\text { Systolic blood pressure } \\
\quad(\mathrm{mmHg})\end{array}$ & $150.60 \pm 10.67^{\mathrm{a}}$ & $209.10 \pm 2.95^{b}$ & $150.60 \pm 10^{\mathrm{a}}$ \\
\hline \multirow[t]{3}{*}{ HOMA-IR } & $0.95 \pm 0.01^{\mathrm{a}}$ & $1.30 \pm 0.01^{\mathrm{b}}$ & $0.75 \pm 0.01^{\mathrm{c}}$ \\
\hline & \multicolumn{3}{|c|}{$8 \mathrm{wk}$} \\
\hline & KW group & SF-SHR group & FO-SHR group \\
\hline $\begin{array}{l}\text { Systolic blood pressure } \\
\text { (mmHg) }\end{array}$ & $142.00 \pm 6.32^{\mathrm{a}}$ & $222.88 \pm 12.32^{\mathrm{b}}$ & $164.53 \pm 11.15^{c}$ \\
\hline HOMA-IR & $2.71 \pm 0.02^{\mathrm{a}}$ & $4.88 \pm 0.04^{\mathrm{b}}$ & $1.58 \pm 0.03^{\mathrm{c}}$ \\
\hline
\end{tabular}

KW: Kyoto-Wistar, SHR: spontaneously hypertensive rats.

KW group, $n=10$; SF-SHR group, $n=10$; SO-SHR group, $n=10$ and FO-SHR group, $n=10$.

Values represent the mean \pm SD. Means in the same row sharing a superscript are statistically similar $(p<0.05)$.

HOMA-IR $=($ Insulin $[\mu \mathrm{U} / \mathrm{mL}])($ glucose $[\mathrm{mmol} / \mathrm{L}]) / 22.5$.

enriched fish oil during 8 wk decreased their blood pressure by $26 \%$.

With respect to insulin resistance, HOMA-IR was higher in SHR groups fed sunflower oil (36\% and 80\%), thus confirming the presence of metabolic syndrome in SHR rats.

This parameter was lower in SHR rats fed sardine oil (42\%) or fish oil enriched with omega-3 (67\%) with respect to rats of the SF-SHR groups, the rats consuming fish oil showed even lower levels in comparison to rats of the group control group.

\section{DISCUSSION}

Hypertension and other chronic diseases (obesity and type 2 diabetes) are associated with insulin resistance (IR) and with environmental determinants like the type of dietary acids $(11,12)$. For this reason, fatty acids have gained nutritional importance, particularly omega3 polyunsaturated fatty acids ( $n-3$ PUFAs) such as EPA and DHA. There are numerous studies using diets high 
in fat or sucrose in which their beneficial effect on insulin sensitivity has been demonstrated (13-15); however, it is unknown if the excessive increase in $n-3$ PUFA intake and the time of consumption have a greater or equal dietary effect on insulin resistance and hypertension.

In this work, the administration of a sardine oil diet for 6 wk did not generate any change in body weight or adipose tissue weight. In contrast, a decrease in body $(8 \%)$ and adipose tissue weight (38\%) was observed after the administration of the $n-3$ enriched fish oil diet for $8 \mathrm{wk}$. The cellular mechanisms related with the results above mentioned have been realized by some researchers who study the effect of $n$-3 PUFA on weight, for example, the $n$ - 3 PUFA increase in the expression of many genes involved in lipid metabolism (16), and transcription factors like PPAR- $\gamma 2$ remodeling the adipose tissue in adult animals, driving the formation of small insulin-sensitive white adipocytes (17).

On the other hand, with respect to blood pressure, feeding white sardine oil or $n$-3 PUFA enriched fish oil showed a similar impact on blood pressure levels; conversely, insulin resistance, evaluated by the HOMA-IR index, diminished to a greater percentage with $n-3$ PUFA enriched fish oil (67\%) compared to sardine oil (42\%).

In connection with the above results, several studies in humans and animals have demonstrated the beneficial effects of $n-3$ PUFA supplementation on insulin sensitivity and blood pressure; feeding with n-3 PUFA improves insulin sensitivity (18), while $n-6$ PUFAs deteriorate the sensitivity to this hormone (19). In addition, numerous epidemiologic studies support these findings in animals and demonstrate that habitual fish intake is inversely associated with the incidence of impaired glucose tolerance and type 2 diabetes (20).

With respect to the results obtained on the increase in the sensitivity to insulin and its relation with the composition of fatty acids of the plasma membrane of adipocytes, we can mention that according to other authors, the $n-3$ PUFAs change the fatty acid composition of membrane phospholipids and modify membrane-mediated processes such as insulin transduction signals, and activities of any enzymes for example lipases and the biosynthesis of eicosanoids (21). On the other hand, $n-3$ PUFAs compete for the same metabolic enzymes as $n-6$ PUFAs (22), so that decreasing the dietary $n-6 / n-3$ ratio increases the concentration of (n-3) into membrane phospholipids, resulting in a decrease of the deleterious eicosanoids and thromboxane formation, while increasing the synthesis of eicosanoids from $n-3$ PUFAs, which promote vasodilatation and are anti-atherogenic.

In relation to the above, the ideal $n-6 / n-3$ ratio is approximately $5: 1$ (23) in order to have a beneficial equilibrium of substrates to synthesize pro-atherogenic and vasoconstrictive versus anti atherogenic and vasodilators eicosanoids. In our case, sardine and $n$ - 3 PUFA enriched fish oils had $n-6 / n-3$ ratios lower than 1 , while the sunflower oil $n-6 / n-3$ ratio was 9.3.

Finally, with respect to the composition of fatty acids of the plasma membrane of the adipocyte, and the effect of the concentration of dietary polyunsaturated fatty acids $n-6$ and $n-3$, we found no drastic changes in the concentration of EPA or DHA in the membrane of the adipocyte of rats that consumed sardine oil for $6 \mathrm{wk}$ or oil rich in $n-3$ PUFA for 8 wk (Tables 3 and 4 ). The above results are similar to those of other authors, who reported that EPA and DHA are not stored in adipose tissue in similar proportion to their dietary concentrations $(24,25)$. We found that the incorporation of DHA and EPA in membranes was in lesser proportions than those found in the diet, which suggests that these fatty acids may be preferentially oxidized and not stored (26-29), favoring the production of antihypertensive and antiatherogenic compounds.

\section{CONCLUSIONS}

The results of this study demonstrate that increasing the concentration of $n-3$ PUFAs by utilizing dietary fish oil rich in EPA and DHA, and a longer intake ( $8 \mathrm{wk}$ ) significantly improved insulin sensitivity in comparison with a lower consumption of $n-3$ PUFAs and shorter feeding time ( $6 \mathrm{wk})$. In the same way, the antihypertensive effect was similar, regardless of the level of intake and time consumption of n-3 PUFAs. These effects could be related to changes in the lipid composition of plasma membrane of adipocytes, oxidation of $n-3$ PUFA, or the type of substrates available for the production of active lipid metabolites acting on insulin resistance and hypertension.

\section{REFERENCES}

1) Hostalek U, Czarnecka D, Koch EM. 2015. Treatment of hypertensive patients with a fixed-dose combination of bisoprolol and amlodipine: Results of a cohort study with more than 10,000 patients. Cardiol Ther $\mathbf{4}$ : 179-190.

2) Mills KT, Bundy JD, Kelly TN, Reed JE, Kearney PM, Reynolds K, Chen J, He J. 2016. Global disparities of hypertension prevalence and control: A systematic analysis of population-based studies from 90 countries. Circulation 134(6): 441-450.

3) Llisterri Caro JL, Rodríguez Roca GC, Alonso Moreno FJ, Banegas Banegas JR, González-Segura Alsina D, Lou Arnal S, Divisón Garrote JA, Sánchez Ruiz T, Santos Rodríguez JA, Barrios Alonso V. 2008. Control de la presión arterial en la población hipertensa española atendida en atención primaria. Estudio PRESCAP 2006. Med Clin (Barc) 130(18): 681-687.

4) Vecka M, Dušejovská M, Stankova B, Zeman M, Vavrova L, Kodydkova J, Slaby A, Zak A. 2012. N-3 polyunsaturated fatty acids in the treatment of atherogenic dyslipidemia. Neuro Endocrinol Lett 33(Suppl 2): 87-92.

5) Griinari JM, Bauman DE. 1999. Biosynthesis of conjugated linoleic acid and its incorporation into meat and milk in ruminants. In: Advances in Conjugated Linoleic Acid Research (Yurawecz MP, Mossoba MM, Kramer JK, Pariza MW, Nelson GJ, eds), Vol 1, p 180-200. AOCS Press, Champaign, IL.

6) Aranceta J, Pérez-Rodrigo C. 2012. Recommended dietary reference intakes, nutritional goals and dietary guidelines for fat and fatty acids: a systematic review. $\mathrm{Br}$ J Nutr 107: 8-22.

7) National Research Council. 1985. Guide for the Care and Use of Laboratory Animals, 1985. Publication no. 
85-23 (revised). National Institutes of Health, Bethesda, MD.

8) Matthews DR, Hosker JP, Rudenski AS, Naylor BA, Treacher DF, Turner RC. 1985. Homeostasis model assessment: insulin resistance and beta-cell function from fasting plasma glucose and insulin concentrations in man. Diabetologia 28(7): 412-419.

9) Belsham GJ, Denton RM, Tanner MJA. 1980. Use of a novel rapid preparation of fat-cell plasma membranes employing Percoll to investigate the effects of insulin and adrenaline on membrane protein phosphorilation within intact fat-cells. Biochem J 192: 457-467.

10) Folch J, Lees M, Sloane-Stanley GH. 1957. A simple method for the isolation and purification of total lipids from animal tissues. J Biol Chem 226: 497-509.

11) Laakso M, Kuusisto J. 2014. Insulin resistance and hyperglycaemia in cardiovascular disease development. Nat Rev Endocrinol 10: 293-302.

12) Ortega E, Amor AJ, Rojo MG, Castell C, Gimenez M, Conget I. 2015. Cardiovascular disease in patients with type 1 and type 2 diabetes in Spain. Med Clin (Barc) 145(6): 233-238.

13) Saidpour A, Zahediasl S, Kimiagar M, Vafa M, Ghasemi A, Abadi A, Daneshpour MS, Zarkesh M. 2011. Fish oil and olive oil can modify insulin resistance and plasma desacyl-ghrelin in rats. Res Med Sci 16(7): 862-871.

14) Yamazaki RK, Brito GA, Coelho I, Pequitto DC, Yamaguchi AA, Borghetti G, Fernandes LC. 2011. Low fish oil intake improves insulin sensitivity, lipid profile and muscle metabolism on insulin resistant MSG-obese rats. Lipids Health Disease 10: 66.

15) Alexander-Aguilera A, Berruezo S, Hernández-Diaz G, Angulo O, Oliart-Ros R. 2011. Dietary n-3 polyunsaturated fatty acids modify fatty acid composition in hepatic and abdominal adipose tissue of sucrose-induced obese rats. J Physiol Biochem 67(4): 595-604.

16) Polus A, Zapala B, Razny U, Gielicz A, Kiec-Wilk B, Malczewska-Malec M, Sanak M, Childs CE, Calder PC, Dembinska-Kiec A. 2016. Omega-3 fatty acid supplementation influences the whole blood transcriptome in women with obesity, associated with pro-resolving lipid mediator production. Biochim Biophys Acta 1861(11): $1746-1755$.

17) Rossi A, Lombardo YB, Lacorte JM, Chicco A, Rouault C, Slama G, Rizkalla SW. 2005. Dietary fish oil positively regulates plasma leptin and adiponectin levels in sucrose-fed, insulin-resistant rats. Am J Physiol Regul Integr Comp Physiol 289: R486-R494.

18) Kalupahana NS, Claycombe K, Newman SJ, Stewart T, Siriwardhana N, Matthan N, Lichtenstein AH, Moustaid-
Moussa N. 2010. Eicosapentaenoic acid prevents and reverses insulin resistance in high-fat diet-induced obese mice via modulation of adipose tissue inflammation. $J$ Nutr 140(11): 1915-1922.

19) de Oliveira Otto MC, Wu JH, Baylin A, Vaidya D, Rich SS, Tsai MY, Jacobs DR Jr, Mozaffarian D. 2013. Circulating and dietary omega- 3 and omega- 6 polyunsaturated fatty acids and incidence of CVD in the Multi-Ethnic Study of Atherosclerosis. J Am Heart Assoc 2(6): e000506.

20) Ogawa S, Abe T, Nako K, Okamura M, Senda M, Sakamoto T, Ito S. 2013. Eicosapentaenoic acid improves glycemic control in elderly bedridden patients with type 2 diabetes. Tohoku J Exp Med 231(1): 63-74.

21) Janovská A, Hatzinikolas G, Mano M, Wittert GA. 2010. The effect of dietary fat content on phospholipid fatty acid profile is muscle fiber type dependent. Am J Physiol Endocrinol Metab 298(4): E779-786.

22) Fèvre C, Bellenger S, Pierre AS, Minville M, Bellenger J, Gresti J, Rialland M, Narce M, Tessier C. 2011. The metabolic cascade leading to eicosanoid precursors-desaturases, elongases, and phospholipases A2-is altered in Zucker fatty rats. Biochim Biophys Acta 1811(6): 409-417.

23) Simopoulos AP, Di Nicolantonio JJ. 2016. The importance of a balanced $\omega-6$ to $\omega-3$ ratio in the prevention and management of obesity. Open Heart 3(2): e000385. eCollection 2016.

24) Hill JO, Peters JC, Lin D, Yakubu F, Greene H, Swift L. 1993. Lipid accumulation and body fat distribution is influenced by type of dietary fat fed to rats. Int J Obes $\mathbf{1 7}$ : 223-236.

25) Lin DS, Connor WE. 1990. Are the n-3 fatty acids from dietary fish oil deposited in the triglyceride stores of adipose tissue? Am J Clin Nutr 51: 535-539.

26) Leyton J, Drury PJ, Crawford MA. 1987. Differential oxidation of saturated and unsaturated fatty acids in vivo in the rat. Br J Nutr 57: 383-393.

27) DeLany JP, Windhauser MM, Champagne CM, Bray GA. 2000. Differential oxidation of individual dietary fatty acids in humans. Am J Clin Nutr 72(4): 905-911.

28) Storlien LH, Kraegen EW, Chisholm DJ, Ford GL, Bruce DG, Pascoe WS. 1987. Fish oil prevents insulin resistance induced by high-fat feeding in rats. Science 237(4817): 885-888.

29) LeMieux MJ, Kalupahana NS, Scoggin S, MoustaidMoussa N. 2015. Eicosapentaenoic acid reduces adipocyte hypertrophy and inflammation in diet-induced obese mice in an adiposity-independent manner. J Nutr 145(3): 411-417. 